\title{
39. PETROGRAPHIC PROPERTIES OF TEPHRAS, LEG 56, DEEP SEA DRILLING PROJECT
}

\author{
Toshio Furuta, Ocean Research Institute, University of Tokyo, Nakano, Tokyo, Japan \\ and \\ Fusao Arai, Department of Geology, Gunma University, Maebashi, Japan
}

\section{INTRODUCTION}

Examining volcanic materials in deep sea sediments may be one of the most important tasks of the Deep Sea Drilling Project. The investigation of volcanic ash near young source volcanoes is particularly helpful in enabling us to infer the history of volcanism in and around the island arcs. In the area of the Japanese islands volcanic deposits are usually distributed east of the source by prevailing westerly winds. It is also possible that some deep sea tephra has its source in a large, already known land volcanism.

During Leg 56, volcanic ash layers from the Miocene to Recent were recovered at Sites 434,435 , and 436 in the northwestern Pacific. In addition, piston core (KH77-1-6) containing two tephra layers was raised by the $R / V$ Hakuho-Maru from the Ocean Research Institute, University of Tokyo. The core site $\left(39^{\circ} 41.4^{\prime} \mathrm{N}\right.$, $\left.145^{\circ} 22.2^{\prime} \mathrm{E}\right) 30 \mathrm{~km}$ southwest of DSDP Site 436 is on the outer swell beyond the Japan Trench. Figure 1 shows the location of all these sites. The present work comprises the following results with respect to these tephras: (1) petrographic study of deep sea tephra layers; (2) examination of characteristic trends in tephra deposition from Miocene to Recent; (3) correlation of tephras among cores.

Tephrochronological correlation and identification have been made by many investigators. For instance, Ninkovich (1968) successfully correlated deep sea tephra layers to a Pleistocene eruption from New Zealand. One of the present authors (Furuta, 1976) demonstrated that petrographic composition of constituent minerals and magnetic properties of $\mathrm{Ti}-\mathrm{Fe}$ oxides can be used to identify specific tephra events, which permits stratigraphic correlation from one section to another.

Meanwhile, identification and correlation among land tephras have long been a main subject in tephrochronology. Westgate (1977), for instance, reported that the Holocene tephra layers in the western territory of Canada could be identified according to significant compositional differences of volcanic glass. Aramaki and Ui (1976) suggested that discrimination of tephra layers in apparently similar petrographic features could be done by using the $\mathrm{Ca}-\mathrm{Mg}-\mathrm{Fe}$ ratio of pyroxene in the pyroclastic deposits of southern Kyushu. Machida and Arai (1976) reported that the refractive indices of volcanic glass, orthopyroxene, and hornblende phenocrysts might be an effective means for correlating widespread tephra layers. By this method they succeeded in tracing a tephra land layer extending more than 1000 $\mathrm{km}$.

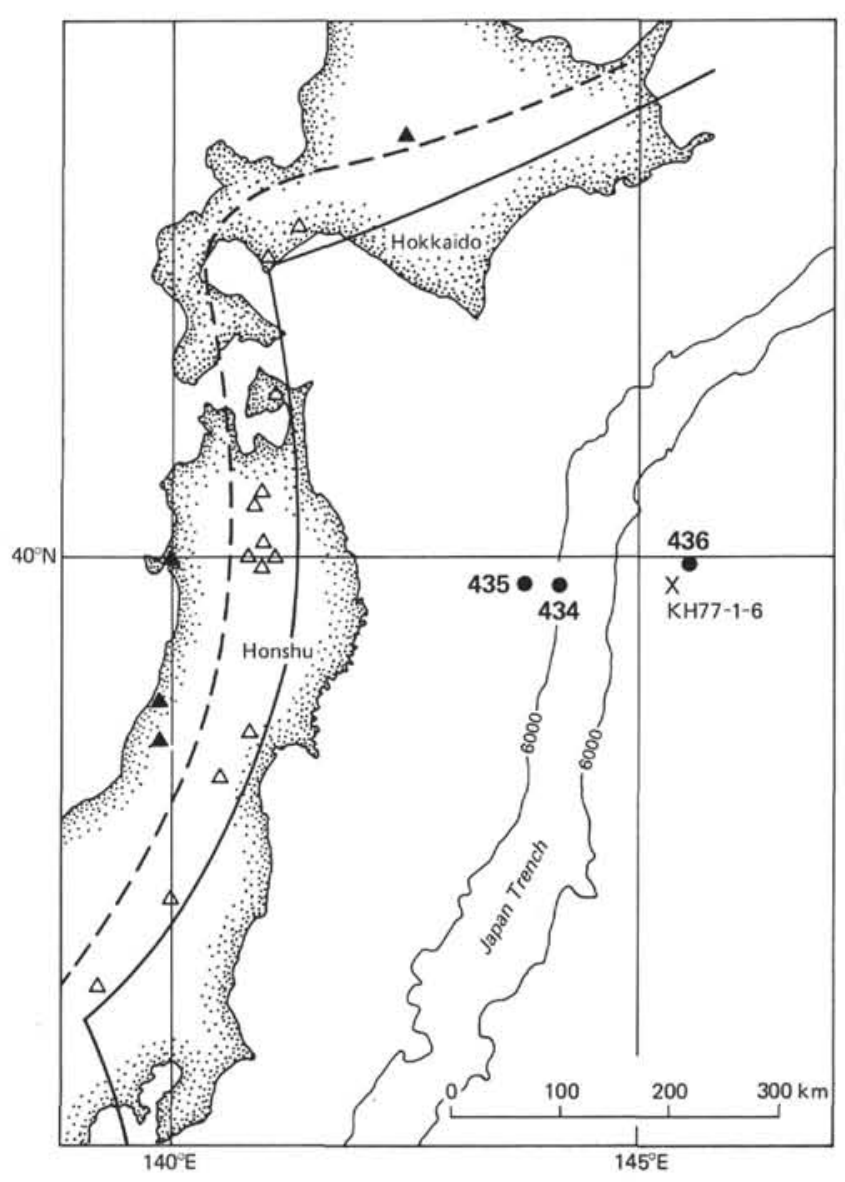

Figure 1. Location map showing for Sites 434, 435, 436 and KH77-1-6. (Solid line denotes the Quaternary volcanic front and dashed line denotes the boundary of tholeiitic rock and high-alumina rock provinces [Kuno, 1960]. $\Delta=$ tholeiitic series, $\boldsymbol{\Delta}=$ high-alumina series.)

\section{EXPERIMENTAL RESULTS}

\section{Refractive Index of Volcanic Glass Shards}

Tephra samples were purified by an ultrasonic cleaner, and clay minerals and dusts smaller than $5 \mu \mathrm{m}$ were sieved off with water. Then the mineral assemblages and type, color, and grain size of volcanic glass shards were examined under the binocular and polarized microscopes. Glass shards are classified into two types, one like pumice, with many vesicles, and the other consisting of bubble-wall glass. The refractive index was measured by the phase contrast technique using mono- 
chromatic illumination at a controlled constant temperature of $24 \pm 0.2^{\circ} \mathrm{C}$. Accuracy of the refraction index of immersion liquids is less than \pm 0.0002 . The results with respect to each sample are expressed in terms of (1) range, denoted by the maximum and minimum values; (2) mean range, or the range within which more than 80 per cent of measured values are concentrated; and (3) modal values (Table 1 and Figure 2).

\section{Chemical Composition of Glass and Pyroxene}

Purified tephra samples were separated into glass and phenocryst fractions by using the Clerici solution with a specific gravity of $2.508 \pm 0.002$. Glass shards and phenocrysts were each cemented with epoxy resin in an acrylic holder. Nine elements of volcanic glass and three elements $(\mathrm{CaO}, \mathrm{MgO}$, and $\mathrm{FeO})$ of pyroxene phenocryst

TABLE 1

Refractive Index of Volcanic Glass Shards

\begin{tabular}{|c|c|c|c|c|c|c|c|c|}
\hline \multirow[b]{2}{*}{$\begin{array}{c}\text { Core/Section } \\
\text { (Interval in } \mathrm{cm} \text { ) }\end{array}$} & \multirow[b]{2}{*}{ Constituent Mineral ${ }^{\mathrm{a}}$} & \multicolumn{3}{|c|}{ Volcanic Glass ${ }^{\mathrm{b}}$} & \multicolumn{3}{|c|}{ Refractive Index $c$} & \multirow[b]{2}{*}{$\begin{array}{c}\text { Glass } \\
\text { (wt. \%) }\end{array}$} \\
\hline & & type & color & $\begin{array}{l}\max . \text { size } \\
(\mathrm{mm})\end{array}$ & range & mean range & mode & \\
\hline \multicolumn{9}{|l|}{ Hole 434} \\
\hline $9-2(8-9)$ & $\mathrm{mt}$ & $\mathrm{pm}$ & $\mathrm{cl}$ & 0.3 & $1.499-1.501$ & & \pm 1.500 & \\
\hline $15-2(51-52)$ & opx cpx ho mt & $\mathrm{pm} \gg \mathrm{bw}$ & $\mathrm{cl}$ & 0.4 & $1.500-1.501$ & & \pm 1.5005 & 71.7 \\
\hline \multicolumn{9}{|l|}{ Hole 434B } \\
\hline $4-1(36-38)$ & opx cpx ho mt & & & 0.3 & $1.500-1.515$ & $1.501-1.505$ & & \\
\hline \multicolumn{9}{|l|}{ Hole 435} \\
\hline $5-6(15-16)$ & opx cpx ho $\mathrm{mt}$ & $\mathrm{pm}$ & $\mathrm{cl}$ & 2.0 & $1.502-1.504$ & & \pm 1.503 & \\
\hline $6-2(131-132)$ & & $\mathrm{pm}$ & $\mathrm{cl}$ & 0.5 & $1.500-1.503$ & $1.501-1.503$ & \pm 1.502 & \\
\hline $6-4(36-37)$ & opx mt cpx ho & $\mathrm{pm}$ & $\mathrm{cl}$ & 0.8 & $1.500-1.503$ & & & \\
\hline \multicolumn{9}{|l|}{ Hole 435A } \\
\hline 3-4 (37-38) & & $\mathrm{pm}$ & $\mathrm{cl}$ & 0.05 & $1.506-1.510$ & $1.509-1.510$ & \pm 1.5095 & \\
\hline $5-3(148-149)$ & & $\mathrm{pm}$ & $\mathrm{cl}$ & 1.0 & $1.503-1.511$ & & & \\
\hline \multicolumn{9}{|l|}{ Hole 436} \\
\hline $\begin{array}{l}1-2(25-26) \\
1-2(86-87)\end{array}$ & no opx mt & & $\begin{array}{l}\mathrm{cl} \\
\mathrm{cl}\end{array}$ & 0.3 & $\begin{array}{l}1.507-1.513 \\
1.507-1.513\end{array}$ & $1.508-1.510$ & \pm 1.510 & $\begin{array}{l}74.4 \\
85.3\end{array}$ \\
\hline $1-4(131-132)$ & & $\begin{array}{l}\mathrm{pm}>\mathrm{bw} \\
\mathrm{pm}>\mathrm{bw}\end{array}$ & $\begin{array}{l}\mathrm{cl} \\
\mathrm{cl}\end{array}$ & $\begin{array}{l}0.3 \\
0.1\end{array}$ & 1.503-1.505 & & \pm 1.504 & 94.1 \\
\hline $3-1(19-20)$ & opx cpx & $\mathrm{pm}$ & $\mathrm{cl}$ & 0.3 & $1.515-1.524$ & $1.517-1.522$ & & 42.9 \\
\hline $3-4(28-29)$ & opx cpx mt & $\mathrm{pm}>\mathrm{bw}$ & $\mathrm{cl}$ & 0.5 & $1.503-1.513$ & $1.504-1.506$ & \pm 1.505 & 81.2 \\
\hline $3-4(59-60)$ & opx cpx mt & $\mathrm{pm}>\mathrm{bw}$ & $\mathrm{cl}$ & 0.5 & $1.503-1.514$ & $1.503-1.508$ & & 69.9 \\
\hline $3-4(87-88)$ & opx cpx mt & $\mathrm{pm}>\mathrm{bw}$ & $\mathrm{cl}$ & 0.5 & $1.503-1.515$ & $1.503-1.505$ & \pm 1.504 & 79.7 \\
\hline $5-2(69-70)$ & opx cpx mt & $\mathrm{pm}>\mathrm{bw}$ & $\mathrm{pl} \mathrm{br}$ & 0.4 & $1.516-1.520$ & $1.516-1.518$ & \pm 1.517 & 61.5 \\
\hline $6-3(132-134)$ & & pm & cl & 0.4 & $1.502-1.505$ & & \pm .504 & 58.3 \\
\hline $6-4(118-120)$ & opx cpx ho mt & $\mathrm{pm}$ & $\mathrm{cl}$ & 0.3 & $1.500-1.509$ & $1.502-1.505$ & & 81.4 \\
\hline $7-2(71-73)$ & ho opx cpx & $\mathrm{pm} \gg \mathrm{bw}$ & $\mathrm{cl}$ & 1.0 & $1.506-1.512$ & $1.506-1.509$ & \pm 1.507 & 59.5 \\
\hline $8-3(14-16)$ & ho bt & $\mathrm{pm}$ & $\mathrm{cl}$ & 0.5 & $1.498-1.501$ & $1.498-1.500$ & \pm 1.499 & 91.9 \\
\hline $9-2(75-77)$ & opx cpx & $\mathrm{pm}>\mathrm{bw}$ & $\mathrm{cl}$ & 0.3 & $1.502-1.510$ & & & 92.2 \\
\hline $10-1(63-65)$ & & $\mathrm{pm}>\mathrm{bw}$ & $\mathrm{cl}$ & 0.1 & $1.504-1.508$ & $1.505-1.507$ & & 97.5 \\
\hline $11-4(53-54)$ & ho opx cpox mt & $\mathrm{pm}$ & $\mathrm{cl}$ & 0.4 & $1.500-1.507$ & $1.500-1.502$ & \pm 1.501 & 61.7 \\
\hline $12-4(131-133)$ & ho bt & $\mathrm{pm} \gg \mathrm{bw}$ & $\mathrm{cl}$ & 0.3 & $1.498-1.510$ & $1.498-1.500$ & \pm 1.499 & 94.1 \\
\hline $14-3(74-76)$ & opx cpx mt & $\mathrm{pm} \gg \mathrm{bw}$ & $\mathrm{pl} \mathrm{br}$ & 0.7 & $1.500-1.505$ & $1.500-1.503$ & \pm 1.502 & 65.2 \\
\hline $15-6(114-116)$ & bt & $\mathrm{pm} \cong \mathrm{bw}$ & $\mathrm{cl}$ & 0.1 & $1.499-1.502$ & $1.500-1.501$ & & 96.6 \\
\hline $15-7(4-6)$ & ho bt & $\mathrm{pm} \cong \mathrm{bw}$ & $\mathrm{cl}$ & 0.1 & $1.500-1.505$ & $1.501-1.503$ & \pm 1.502 & 91.9 \\
\hline $16-3(102-104)$ & opx cpx mt & $\mathrm{pm}>\mathrm{bw}$ & $\mathrm{cl}$ & 0.3 & $1.503-1.516$ & $1.511-1.514$ & & 82.8 \\
\hline $17-1(138-140)$ & & $\mathrm{pm}>$ bw & pl br & 0.4 & $1.500-1.520$ & $1.501-1.512$ & & \\
\hline $17-3(47-49)$ & opx ho & $\mathrm{pm} \gg \mathrm{bw}$ & $\mathrm{cl}$ & 0.3 & $1.500-1.502$ & $1.500-1.501$ & \pm 1.5005 & 95.6 \\
\hline $20-1(67-69)$ & & $\mathrm{pm} \gg \mathrm{bw}$ & $\mathrm{cl}$ & 0.3 & $1.499-1.501$ & & \pm 1.500 & 98.8 \\
\hline $23-5(92-94)$ & $\mathrm{mt}$ ho & $\mathrm{pm}$ & $\mathrm{cl}$ & 0.2 & $1.502-1.508$ & $1.504-1.507$ & & \\
\hline $27-3(9-10)$ & $\mathrm{mt}$ ho & bw & $\mathrm{cl}$ & 0.3 & $1.502-1.503$ & & \pm 1.5025 & 97.3 \\
\hline $29-1(114-116)$ & & $\mathrm{pm}>\mathrm{bw}$ & $\mathrm{cl}$ & 0.1 & $1.504-1.507$ & $1.505-1.506$ & & 93.4 \\
\hline $30-3(82-84)$ & opx cpx mt & $\mathrm{pm} \gg \mathrm{bw}$ & $\mathrm{cl}$ & 0.3 & $1.502-1.508$ & $1.502-1.505$ & & 88.6 \\
\hline $31-1(37-38)$ & & $\mathrm{pm}>$ bw & $\mathrm{cl}$ & 0.2 & $1.500-1.503$ & $1.501-1.503$ & \pm 1.502 & \\
\hline $38-2(27-29)$ & & $\mathrm{pm} \cong \mathrm{bw}$ & $\mathrm{cl}$ & 0.2 & $1.509-1.520$ & $1.510-1.513$ & & \\
\hline Sample KH77-1-6-1 & opx cpx mt & $\mathrm{bw}>\mathrm{pm}$ & cl & 0.3 & $1.504-1.511$ & $1.507-1.510$ & & \\
\hline Sample KH77-1-6-2 & opx cpx mt & $\mathrm{bw}>\mathrm{pm}$ & cl & 0.1 & $1.502-1.504$ & & \pm 1.503 & \\
\hline
\end{tabular}

\footnotetext{
${ }^{\mathrm{a}} \mathrm{Abbreviations}$ and symbols in constituent minerals: $\mathrm{opx}=$ orthopyroxene, $\mathrm{cpx}=$ clinopyroxene ho $=$ hornblende, $\mathrm{bt}=\mathrm{biotite}$, $\mathrm{mt}=$ magnetite, and a blank $=$ not determined.

Type and color of volcanic glass: $\mathrm{pm}=$ pumice-type glass, $\mathrm{bw}=$ bubble-wall type, $\mathrm{cl}=\mathrm{clear}, \mathrm{pl}=\mathrm{pale}$, and $\mathrm{br}=\mathrm{brown}$.

"Refractive index shows range, mean range, and mode of individual layers; "range" denotes the minimum and maximum refractive index, "mean range" is that within which 80 per cent of the measured values fall; "mode" denotes the most concentrated value of the refractive index.
} 


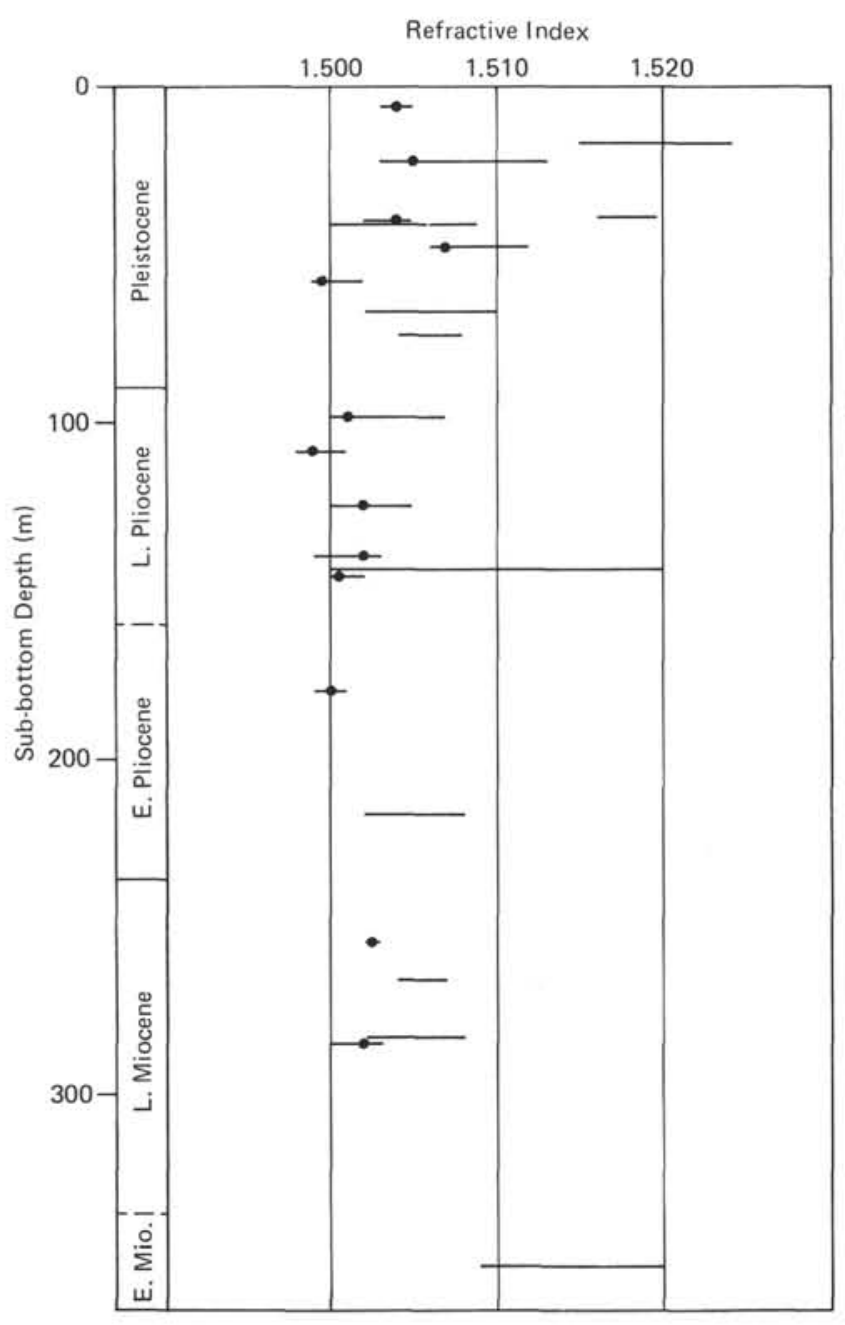

Figure 2. Refractive index of volcanic glass shards in Site 436 tephra layers. $(-=$ range, $\longrightarrow$ - mode.)

were determined by electron probe microanalyzer. The results are shown in Table 2 and in Figures 3 and 4. Composition of pyroxene is represented by Wo, En, and Fs only as stoichiometric pyroxene $(\mathrm{Ca}, \mathrm{Mg}, \mathrm{Fe}) \mathrm{SiO}_{3}$.

\section{PETROGRAPHIC FEATURES}

Table 1 shows the refractive index of volcanic glass shards from 3 tephra layers from Site 434 and 5 from Site 435 (both located on the landward slope of the Japan Trench) and from 29 layers from Site 436 and 2 from Site KH77-1-6 (both in the basin outside the Japan Trench). Type, color, and grain size of volcanic glass shards and composition of constituent minerals are also shown in Table 1.

Because the recovery of tephra layers from Site 436, ranging from Miocene to Recent, was best, we will concentrate on the petrographic results from this site.

Refractive indices of volcanic glass shards in each tephra layer range between 1.498 and 1.524. Some tephra layers showing a narrow range of refractive index may be the result of a single air-fall deposition, whereas others with a wide range may contain tephras from more than one source. In the latter case mixing can be detected by sample analysis.

In the Pleistocene section there are 14 layers in which the refractive indices of the volcanic glass shards have modes within the range of 1.500 to 1.518 , whereas in the Pliocene and Miocene sections most tephra layers have refractive indices whose modes are less than 1.504, except for Samples 436-7-2 and 436-38-2. Samples 436-1-2, 436-1-4, and 436-11-4 can be correlated to Samples KH77-1-6-1, KH77-1-6-2, and 434-15-2, respectively, by the refractive index of the volcanic glass shards (see following section). Eight samples of volcanic glass shards including the aforementioned were analyzed chemically. The results are shown in Table 1 and Figure 3. The relative abundance of $\mathrm{CaO}-\mathrm{FeO}-\mathrm{K}_{2} \mathrm{O}$ is calculated and indicates a wide range of variation in the chemical composition of these volcanic glasses. The $\mathrm{K}_{2} \mathrm{O} / \mathrm{CaO}+\mathrm{FeC}+\mathrm{K}_{2} \mathrm{O}$ ratio of these samples shows a range in value of 0.2 to 0.8 . Thus this rate is useful as an identification criterion for tephra layers. The tephra layers which were chemically analyzed for the nine elements were also analyzed for the $\mathrm{CaO}, \mathrm{MgO}$, and $\mathrm{FeO}$ content of pyroxene phenocrysts. In Figure 4 the composition of the orthopyroxene is plotted on Wo-En-Fs diagrams. As the figure shows, the En-component varies from 0.5 to 0.7 , and the Wo-component ranges from 0.02 to 0.04 . Though the En-component of Sample 436-3-4 shows small variation, the same component in Sample 436-14-3 shows a wide variation-a common phenomenon in these tephras.

\section{CORRELATION OF TEPHRA LAYERS}

Correlation of tephra layers between deep sea and land sediments is one of the most promising aspects of tephrochronology. Because tephra layers covering a broad area provide an excellent time horizon, long-distance correlation among sites is possible. Because of the small number of samples, we have not yet made an extensive correlation but we have found that two tephra layers in DSDP cores correlate to those in Core KH77-1-6 tephra.

Most of our analytical data show their chemical composition to be that of sialic magma such as rhyolite or dacite; therefore we may tentatively assume their source in the northwestern Pacific Basin to be the Japanese Islands. This is a natural assumption because the eruption of sialic volcanoes is sufficiently large scale to have transported the tephra a long distance. The petrographical data we present for deep sea tephra layers make possible correlation to those on land.

Petrographic correlation has been made when tephra layers can be compared according to petrographic features and possess a similar biostratigraphy. Within a single tephra layer, grain size was found to increase in a westward direction.

According to these criteria, one tephra layer from Site 434, three from Site 436, and two from Site KH77-1-6 are correlated with each other by the refractive index of the glass. The refractive index of Sample 434-15-2 ranges from 1.500 to 1.501 , showing a very small dispersion, and its mode is \pm 1.5005 . The chemi- 
TABLE 2

Chemical Composition of Volcanic Glass Shards

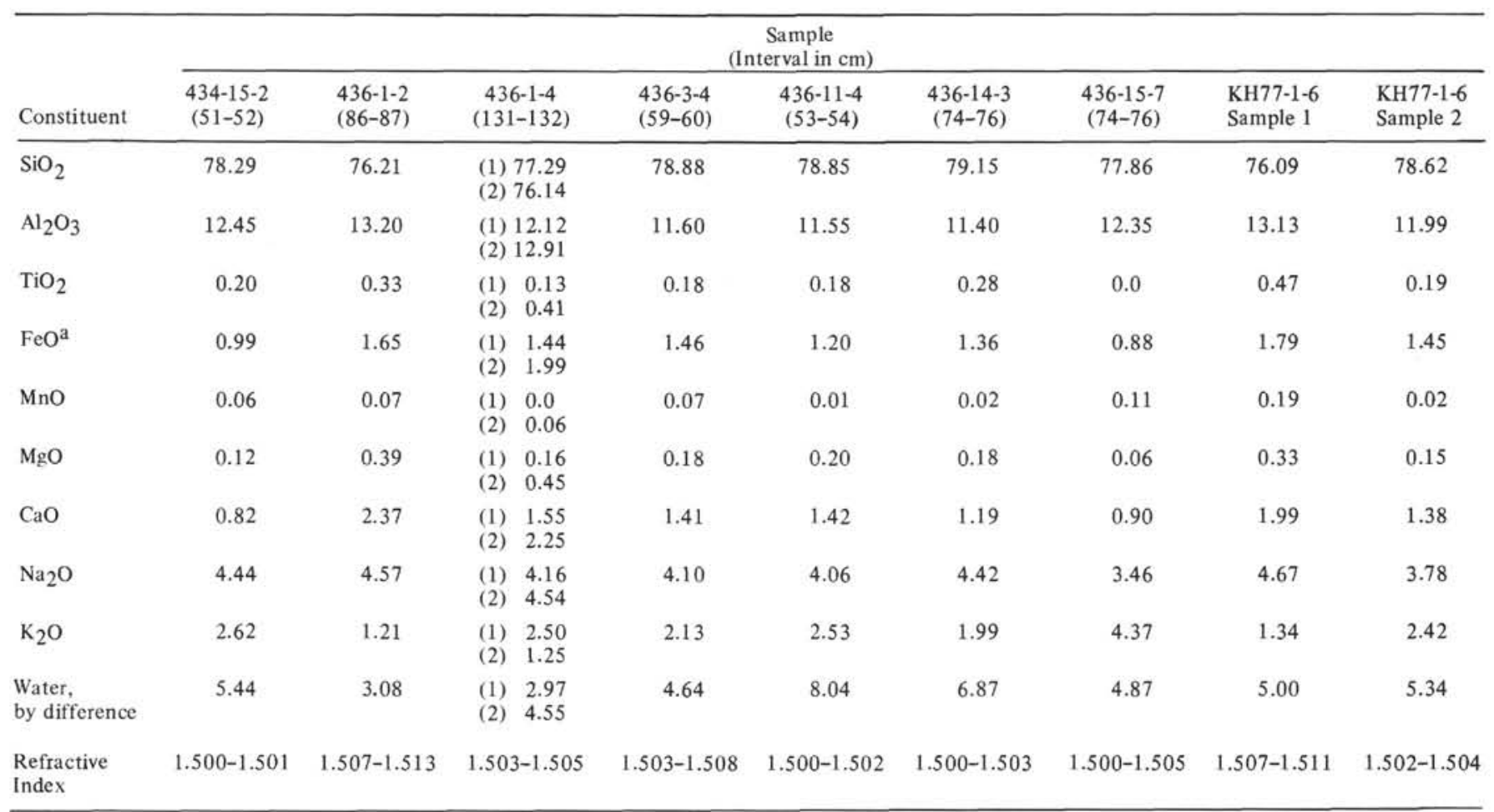

Total iron is given as $\mathrm{FeO}$.

This layer is divided into two groups: $(1)=\mathrm{K}_{2} \mathrm{O}$-rich and $(2)=\mathrm{K}_{2} \mathrm{O}$-poor.

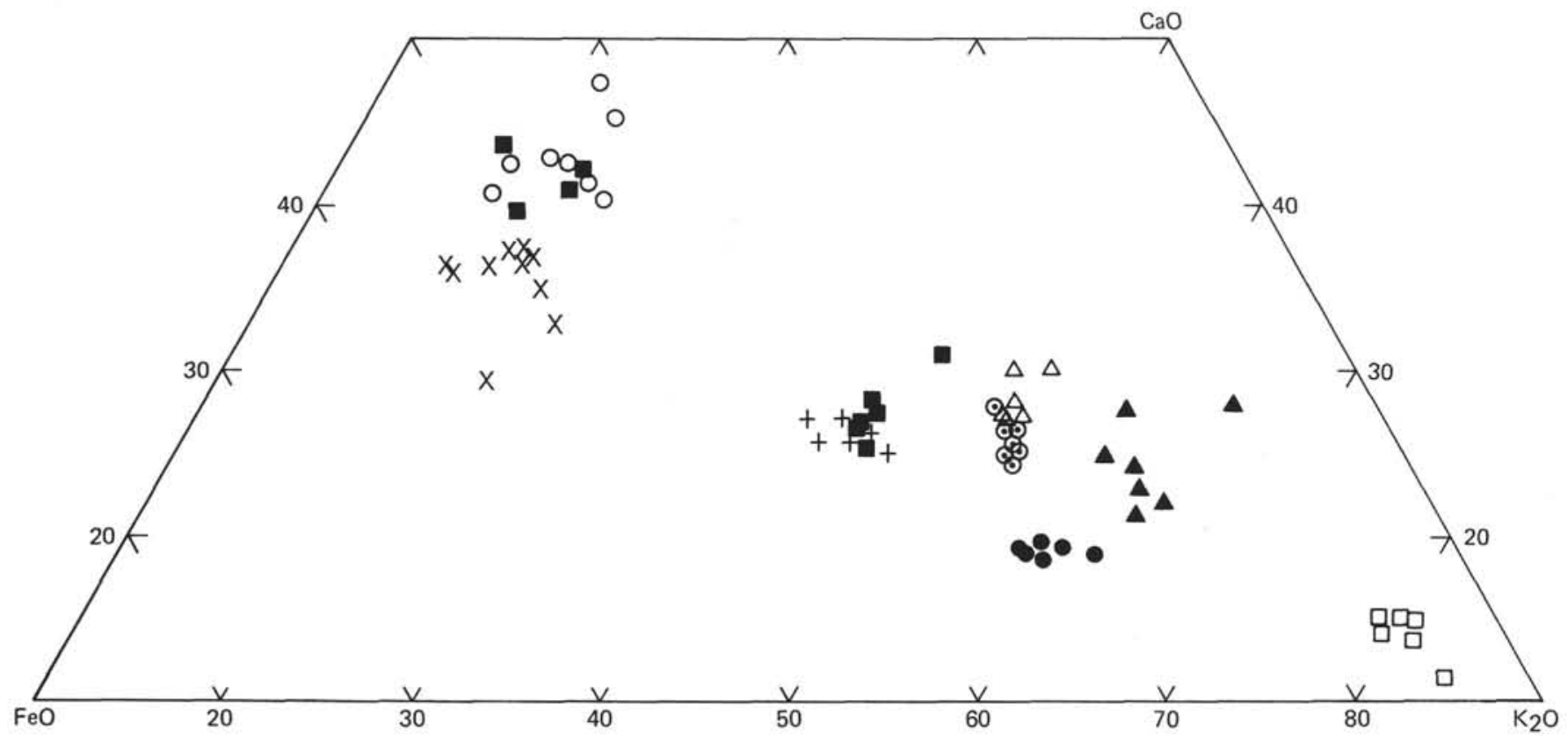

Figure 3. Triangular diagram portraying relative abundances of $\mathrm{CaO}, \mathrm{FeO}$, and $\mathrm{K}_{2} \mathrm{O}$ in volcanic glass shards in tephra layers at Sites 434, 436, and KH77-1-6. $(\bullet=434-15-2(51-52), O=436-1-2(86-87), \boldsymbol{\square}=436-1-4(131-132), \triangle$ $=436-3-4(59-60), \boldsymbol{\Delta}=436-11-4(53-54), \odot=436-14-3(74-76), \square=436-15-7(4-6), \times=K H 77-1-6-1,+=$ KH77-1-6-2.) 

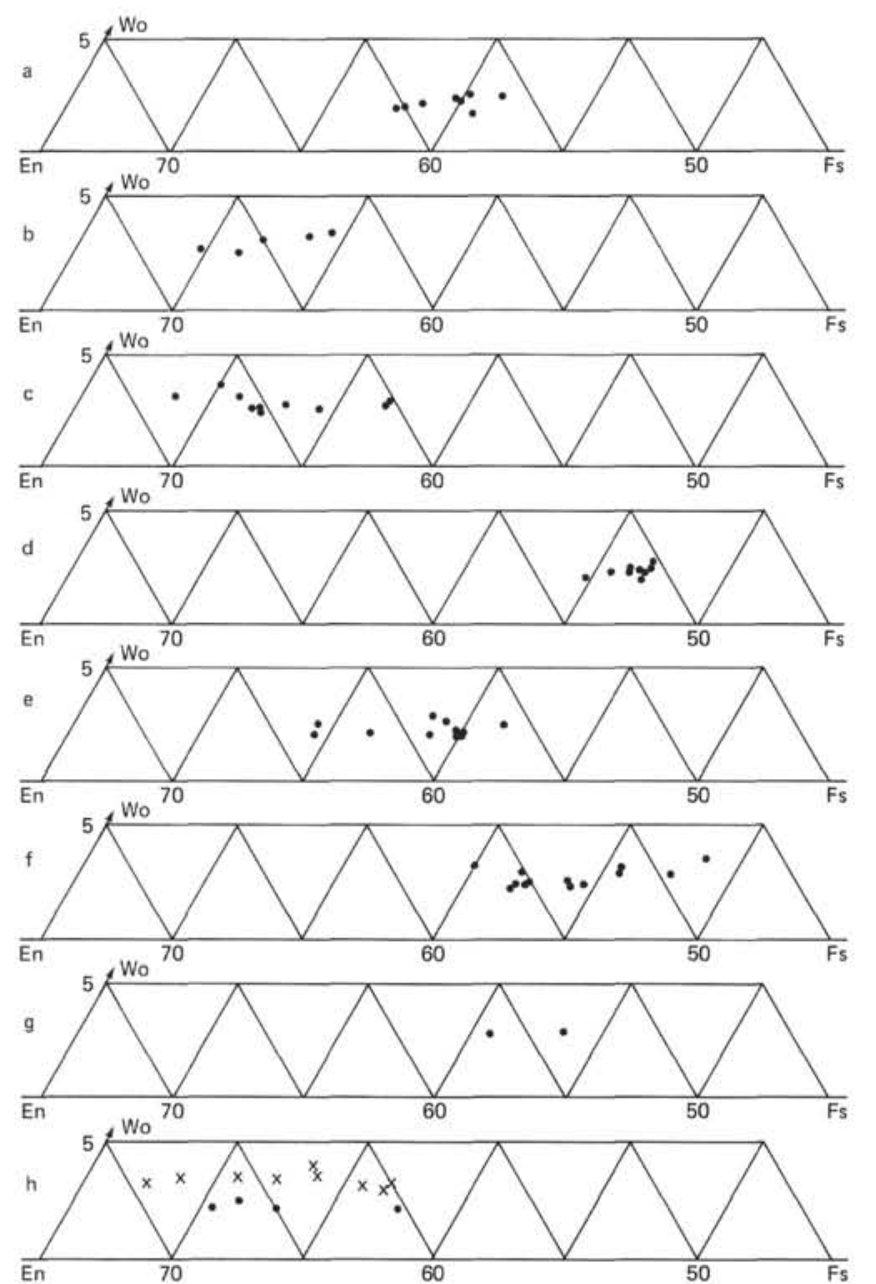

Figure 4. Composition of orthopyroxene phenocrysts plotted in pyroxene quadrilaterals. Results are from partial analyses for $\mathrm{Ca}, \mathrm{Mg}$, and $\mathrm{Fe}$, corrected against ideal pyroxene stoichiometry $(\mathrm{Ca}, \mathrm{Mg}, \mathrm{Fe})$ $\mathrm{SiO}_{3}$. $(a=434-15-2, b=436-1-2, c=436-1-4, d=$ $436-3-4, e=436-11-4, f=436-14-3, g=436-15-7, h$ $=K H 77-1-6-1[\times]$ and $K H 77-1-6-2[\bullet]$.

cal composition of glass in Sample 434-15-2 is shown in Table 2, and the $\mathrm{FeO} / \mathrm{CaO}+\mathrm{FeO}+\mathrm{K}_{2} \mathrm{O}$ ratio is \pm 0.25 (Figure 3). Composition of orthopyroxene in this layer shows a molecular ratio $\mathrm{En}=0.57-0.61$ (Figure 4). The refractive index of the 436-11-4 sample ranges from 1.500 to 1.507 , and its mode is \pm 1.501 . Its $\mathrm{FeO} / \mathrm{CaO}+\mathrm{FeO}+\mathrm{K}_{2} \mathrm{O}$ ratio is \pm 0.24 (Figure 3). Composition of orthopyroxene of this layer shows En $=0.57-0.64$ (Figure 4). Moreover, the $\gamma$-refractive index of orthopyroxene phenocrysts in Samples 434-15-2 and 436-11-4 show a value from 1.713 to 1.717 and from 1.713 to 1.716 , respectively. Both values correspond to the compositional ranges of these orthopyroxenes. Other petrographic features (e.g., constituent minerals, type of glass, color, and grain size) of both layers are very similar to each other. Their biostratigraphic age is approximately late Miocene.

At Site 436 the two youngest tephra layers at the top of the core correlate to the layers in piston core
KH77-1-6. Core KH77-1-6, $450 \mathrm{~cm}$ long, sampled at $39^{\circ} 41.4^{\prime} \mathrm{N}, 145^{\circ} 22.2^{\prime} \mathrm{E}$, includes two tephra layers. Tephra layers in Samples 436-1-2 and 436-1-4 correlate by their petrographic features to the tephra layers of Samples KH77-1-6-1 and KH77-1-6-2, respectively.

\section{DISCUSSION}

Because many tephra layers have been identified in the upper portion of the Site 436 (Miocene to Recent), we will discuss several characteristic features.

1) There are 56 tephra layers in the Pleistocene, 31 in the late Pliocene, 27 in the early Pliocene, 20 in the late Miocene, and 12 in the early Miocene. It is clear that the number of tephra layers decreases downward through the core.

2) Detailed petrographic properties of glass shards at Site 436 show that layers in the upper part of Hole 436 are both sialic and slightly less sialic in composition, whereas in the lower part they are only sialic. Volcanoes, especially those ejecting rhyolitic magma, have furiously explosive activity and expel a vast amount of volcanic material. The slightly less sialic tephra in the upper part of the hole may originate from a relatively small eruption of nonsialic Japanese volcanoes.

3) As regards grain size of volcanic glass, it increases inversely with age; thus the younger the tephra, the larger the grain size.

4) Analysis of the chemical composition of the glass in Sample 436-1-4 clearly shows it to be composed of mixed tephra from at least two different sources.

Observations (1) through (3) can best be explained by assuming that deposition in the lower part of Hole 436 occurred when the site was far to the east of its present position.

\section{CONCLUSIONS}

1) Two Pleistocene tephra layers, from Sites 436 and KH77-1-6, and one Miocene tephra layer at Sites 434 and 436 were correlated according to the refractive index and chemical composition of volcanic glass, the chemical composition of pyroxene phenocrysts, and other petrographic properties.

2) Both the increase in the number of tephra layers and the range in chemical composition of volcanic glass from Miocene to Recent can best be explained according to the principles of plate tectonics, whereby Site 436 on the Pacific Plate moved toward the subduction zone during this time interval.

3) The refractive index and the chemical composition of volcanic glass shards have proved to be powerful tools for the identification and correlation of deep sea tephra up to Miocene.

\section{ACKNOWLEDGMENTS}

The authors are very grateful to Kazuo Kobayashi and Kunio Kobayashi for valuable suggestions and a critical reading of the manuscript.

\section{REFERENCES}

Aramaki, S., and Ui, T., 1976. Pyroclastic deposits in southern $\mathrm{Kyushu}-\mathrm{A}$ correlation by the $\mathrm{CaO}-\mathrm{MgO}-\mathrm{FeO}$ ratios 
of phenocrystic minerals. Bull. Earthq. Res. Inst., 51, $158-182$.

Furuta, T., 1976. Petrographic and magnetic properties of tephra in a deep-sea core from the northwest Pacific. Mar. Geol., 20, 229-237.

Kuno, H., 1960. High alumina basalt. J. Petrol., 1, 121-145.

Machida, H., and Arai, F., 1976. The very widespread tephra -The Aira-Tn ash. Kagaku (Science), 46, 339-347. (in Japanese)
Ninkovich, D., 1968. Pleistocene volcanic eruption in New Zealand recorded in deep-sea sediments. Earth Planet. Sci. Lett., 1, 89-102.

Westgate, J. A., 1977. Identification and significance of late Holocene tephra from Otter Creek, southern British Columbia, and localities in west-central Alberta. Can. J. Sci., 14, 2593-2600. 